\title{
Award-winning paper in 2013
}

Papers published in Engineering History and Heritage are eligible for awards
from the Institution of Civil Engineers. Papers from any of the ICE journals can be nominated for several awards. In addition, each journal has awards dedicated to their specific subject area.

On Friday 17 October 2014, ICE president Geoff French presented an award to the following paper published in Engineering History and Heritage in 2013. The editorial panel nominated their best papers and an awards committee chaired by Quentin Leiper allocated the awards.

\section{Telford Premium Prize}

The Telford Premium Prize was awarded to Birnstiel (2013).

\section{Abstract}

On 6 December 1825 a cable-stayed road bridge at Nienburg-on-the-Saale, Germany, collapsed with the loss of 55 lives. It was the first cable-stayed bridge with a roadway for team-drawn wagons and with two sidewalks for pedestrians and spanned $79 \mathrm{~m}$ between towers, with a double-leaf bascule at midspan to permit passage of sailing vessel masts. The disaster contributed to the negative attitude towards bridges supported by a multiplicity of tensile stays, which persisted until after World War II. As Nienburg recovered from the Napoleonic Wars it needed a bridge across the Saale but a conventional masonry arch bridge was unaffordable. A local building official, Gottfried Bandhauer, proposed a cable-stayed design. There were serious quality control problems during construction, but the bridge was tested and opened to traffic in September 1825. It collapsed 3 months later during a celebration honouring the Duke. The bridge structure, the events leading to the collapse, and the post-collapse investigations are related in this paper, including results of approximate static and dynamic analyses. The purpose of this paper is to relate the history of the bridge and the consequences of engineering designs that are too advanced for the artisans at the time and place.

\section{REFERENCE}

Birnstiel (2013) Collapse of a cable-stayed road bridge in Germany in 1825. Proceedings of the Institution of Civil Engineers - Engineering History and Heritage 166(4): 207226, http://dx.doi.org/10.1680/ehah.13.00007. 